\title{
Reef accessibility impairs the protection of sharks
}

JUHEL Jean-Baptiste ${ }^{a b c}$, VIGLIOLA Laurent ${ }^{b}$, MOUILLOT David ${ }^{c, d}$, KULBICKI Michel $^{e}$, LETESSIER Tom B. ${ }^{\text {f,g }}$, MEEUWIG Jessica J. ${ }^{\mathrm{g}}$, WANTIEZ Laurent ${ }^{\mathrm{a}}$

a Université de la Nouvelle-Calédonie, LIVE EA1314, BPR4, 98851 Noumea, New Caledonia.

${ }^{\mathrm{b}}$ Institut de recherche pour le développement (IRD), UMR ENTROPIE, Laboratoire Excellence LABEX Corail, Noumea, New Caledonia.

c Université de Montpellier, UMR 9190 MARBEC, CC 093, 34095 Montpellier Cedex 5, France.

${ }^{d}$ Australian Research Council Centre of Excellence for Coral Reef Studies, James Cook University, Townsville, QLD 4811 Australia.

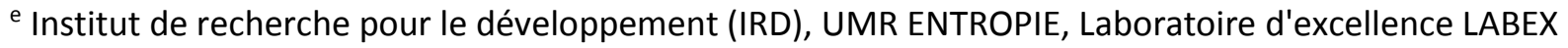
Corail, Université de Perpignan,66000 Perpignan, France.

${ }^{f}$ Institute of Zoology, Zoological Society of London, Regent's Park, London NW1 4RY

${ }^{g}$ Centre for Marine Futures, Oceans Institute and School of Animal Biology, The University of Western Australia, (M470), 35 Stirling Highway, Crawley WA 6009.

Corresponding author: Jean-Baptiste Juhel

jean-baptiste.juhel@umontpellier.fr

Running title: Impairment of shark protection

Word count: total $(7,045)$, abstract $(304)$, main text $(4,150)$, acknowledgements $(86)$, references $(2,016)$, tables legends (127), figure legends (362) 


\section{Number of figures: 5}

\section{Number of tables: 3}

Number of references: 67

\section{Abstract}

1. Reef sharks are declining worldwide under ever increasing fishing pressure with potential consequences on ecosystem functioning. Marine protected areas (MPAs) are currently one of the management tools to counteract the pervasive impacts of fishing. However, MPAs in which reef sharks are abundant are often located in remote and underexploited areas preventing a fair assessment of management effectiveness beyond remoteness from human activities.

2. Here we determine the conditions under which MPAs can effectively protect sharks along a wide gradient of reef accessibility, from the vicinity of a regional capital towards remote areas, using 385 records from Baited Remote Underwater Video Systems (BRUVS) and 2790 Underwater Visual Censuses (UVC) performed in areas open to fishing and inside 15 MPAs across New Caledonia (southwestern Pacific).

3. We show that even one of the world's oldest (43 years), large $\left(172 \mathrm{~km}^{2}\right)$ and most restrictive (noentry) MPA (Merlet reserve) on coral reefs has between $17.3 \%$ and $45.3 \%$ fewer shark species and between $37.2 \%$ and $79.8 \%$ fewer shark abundance than remote areas in a context where sharks are not historically exploited.

4. On coral reefs situated at less than 1 hour of travel time from humans, shark populations are so severely depleted (less than 0.05 individuals per $1000 \mathrm{~m}^{2}$ ) that their functional roles may be considered as ecologically extinct. 
5. Synthesis and applications. Remote areas are thus the last sanctuaries for reef sharks and provide a new baseline to evaluate human impacts with no equivalency as one gets closer to human activities even in large, old and strongly restrictive MPAs. As such they deserve strong protection efforts. The large and no-entry MPAs provide limited benefits for reef shark populations but provide realistic conservation targets close to humans. The exclusion of human activities on a sufficiently large area is key to protect reef shark populations.

Keywords: Baited Remote Underwater Video System (BRUVS), Baseline, Elasmobranch, Human proximity, Marine protected area, Pristine coral reef, Underwater Visual Census (UVC)

\section{Introduction}

Reef sharks are 'flagship' species that facilitate the raising of awareness, funding for conservation and socioeconomic benefits through tourism (Brunnschweiler \& Ward-Paige 2014, Cisneros-Montemayor et al. 2013) and play unique ecological roles in coastal ecosystems (Roff et al. 2016). Under the rise of fishing, reef shark populations have been severely depleted worldwide (Rizzari et al 2014a, Nadon et al. 2012, Graham et al. 2010). Extinction risk for sharks is higher than for most other marine vertebrates since they cumulate two features putting them at double jeopardy of extinction: their intrinsic sensitivity to overexploitation due to their large body size and other life history traits (e.g. slow growth rate, long gestation and small litter size) and their exposure to fishing due to international trade of highly priced dried fins (McClenachan et al. 2016, Dulvy et al. 2014, Robbins et al. 2006). However, management actions for reef sharks are limited with no international or bilateral harvest limits and few reliable data. As a consequence, 9 of the 29 reef shark species are designated as data deficient in the IUCN Red List while three-fourths of reef sharks had unknown population trends at the time of their assessment (Dulvy et al. 2014, Field et al. 2009). 
Marine Protected Areas (MPAs) are recognized as management tools that can potentially reduce the decline of reef shark populations (Espinoza et al. 2014, McCook et al. 2011, Robbins et al. 2006) but such assessments usually come from large MPAs located in remote areas (e.g. Chagos, Hawaii Islands or some parts of the Great Barrier Reef) where human activities are de facto restricted (Maire et al. 2016, Devillers et al. 2014). If we focus on small $\left(<100 \mathrm{~km}^{2}\right)$, young or weakly enforced (e.g. partial fishery closure) MPAs, the protection of reef sharks appears ineffective (Edgar et al. 2014, Ward-Paige et al. 2010). The conservation effectiveness of old, large and strongly enforced no-entry MPAs in a humandominated seascape still need additional information for reef sharks. In fact, this effectiveness assessment requires comparisons with both nearby exploited areas and remote areas that can serve as extreme benchmarks along a continuum (Edgar et al. 2014, Dagata et al. 2016).

Here we tested the extent to which and under which conditions MPAs can counteract human impacts to sustain the same species richness and abundance of reef sharks as in remote areas. We used an extensive survey of reef sharks in New Caledonia (South-Western Pacific) comprising 385 samples from Baited Remote Underwater Video Systems (BRUVS) and 2790 Underwater Visual Censuses (UVC) performed inside and outside 15 MPAs (Fig. 1, Table 1) along a gradient of isolation from accessible areas, close to the regional capital (Nouméa), towards remote areas located at more than 25 hours of travel time from Nouméa (Fig. 1A). New Caledonia is the archetypal situation where the protection of sharks should be effective, even close to human activities, since (i) commercial and recreational shark fishing is historically absent and has been banned since 2013 in the exclusive economic zone, and (ii) some MPAs apply severe restrictions on human activities, one of these (Merlet reserve) being one of the world's oldest (43 years) and largest $\left(172 \mathrm{~km}^{2}\right)$ no-entry MPA on coral reefs. Our ultimate goal is thus to compare, while controlling for environmental factors, the species richness and abundance of sharks in the Merlet MPA to those found in accessible and in remote areas open to fishing, in smaller and less protected MPAs and in a remote no-entry MPA. 


\section{Materials and Methods}

\section{Study site}

New Caledonia is an archipelago composed of a $400 \mathrm{~km}$ long main island ("Grande Terre") and a series of smaller islands (Fig. 1A). Coral reefs cover $4,537 \mathrm{~km}^{2}$ in New Caledonia and include one of the largest barrier reefs in the world (1,600 km long). Its extent and its location near the Coral Triangle (marine area extending from Malaysia to Solomon Islands) make New Caledonia a rich location for reef sharks (Chen \& Kishino 2015). Human population density is spatially distributed along a marked gradient from Noumea in the south-west, which hosts two-thirds of the total population $(268,767$ inhabitants in 2014$)$, towards sparsely populated northern and eastern parts of the main island. Different management restrictions are applied in 15 MPAs around New Caledonia (Table 1).

\section{Baited remote underwater videos}

Baited Remote Underwater Videos Systems (BRUVS) were deployed by day on coral reefs at a mean depth of $15.9 \mathrm{~m}$ ( $\pm 9.7 \mathrm{~m} \mathrm{SD}$, range=3-48 m) from September 2012 to October 2014 (Fig. 1B). BRUVS consist of a stereo-video system recording for $1 \mathrm{~h}$ with $1 \mathrm{~kg}$ of crushed pilchards (Sardinops sagax) placed in a wire-meshed bag and suspended approximately $1.5 \mathrm{~m}$ in front of the cameras (Fig. 2, Cappo et al. 2006). High definition videos were analyzed using the EventMeasure software (http://www.seagis.com.au/event.html). Species richness was estimated using the number of shark species seen on the video and abundance was estimated using MaxN, the maximum number of individuals of the same species observed on any single image of the video (Cappo et al. 2006). 


\section{Underwater visual censuses}

Distance sampling Underwater Visual Censuses (UVC) (Labrosse et al. 2002) were performed on reefs at 1 to $15 \mathrm{~m}$ depth from July 1986 to September 2014 (Fig. 1B). These surveys consist of recording the species name, abundance, fork length and distance to transect line of fishes located on each side of a 50 $\mathrm{m}$ long transect surveyed by divers. When performed by two divers, each census took between 20 and 80 minutes. This method is based on the probability to record species as a function of distance from divers (Kulbicki \& Sarramegna 1999). As $90 \%$ of shark observations were at distances $<10 \mathrm{~m}$ from the transect line, raw distance-sampling datasets have been truncated at a distance of $10 \mathrm{~m}$. Shark abundance and species richness were estimated in $1000 \mathrm{~m}^{2}$ equivalent belt transects $(50 \mathrm{~m}$ long $\times 10 \mathrm{~m}$ wide $\times 2$ sides). Transects with water visibility $<10 \mathrm{~m}$ were removed from the analyses.

\section{Explanatory variables}

Three key environmental variables (sea surface temperature, coral reef habitat type and coral reef surface area) and three human related variables (management, accessibility from the market and human population density), all known to be the primary predictors of change in coral reef ecosystems (Cinner et al. 2016, Maire et al. 2016, Williams et al. 2015, Espinoza et al. 2014), were considered to model the species richness and abundance of reef sharks.

Mean Sea Surface Temperature (SST) over the last 10 years (http://podaac.jpl.nasa.gov/) was used. Coral reef habitat type, which includes distance to the shoreline and depth, was coded as a categorical variable (fringing reef, lagoon reef, back reef, outer reef). Reef surface area was quantified in a 20-km buffer around each survey using the $2 \mathrm{~d}$ coverage on a $30 \mathrm{~m}^{2}$ resolution coral reef map. Sea surface temperature, habitat type and reef surface area can influence the abundance and diversity of fishes in this region including the density of shark preys (Dagata et al. 2016). 
Three variables related to human impacts were considered: human density, reef accessibility to humans and management. Human population density was calculated based on the sum of human population in a $25-\mathrm{km}$ buffer centered at the nearest landing point from the census divided by reef area within a $20-\mathrm{km}$ buffer around the census. The $25-\mathrm{km}$ buffer encompasses the land between the shoreline and the mountain chain that separates the two coasts of the main island. As UVC surveys covered a period of 28 years, demographic data from 4 different population censuses were used in the calculation of human density (1989, 1996, 2004 and 2009, www.isee.nc).

The level of human impact on a given reef is also related to its accessibility from the regional capital or domestic markets (Cinner et al. 2016, Maire et al. 2016, Brewer et al. 2013, Cinner et al. 2009). We thus assumed that sharks living on coral reefs with a long travel time from Nouméa will be less impacted than those on easily accessible reefs.

Accessibility from human population was estimated using the travel time from the capital city, which accounts for two-thirds of the territory's population, to reach each surveyed reef according to the method developed in Maire et al. (2016). This travel time was calculated based on the sum of the duration of each segment included in the travel. We used different mean speeds to describe the segments taking into account the environment: in the open ocean (10 knots, $18.5 \mathrm{~km} / \mathrm{h}$ ) and in the lagoon (15 knots, $27.8 \mathrm{~km} / \mathrm{h})$, and on roads $(75 \mathrm{~km} / \mathrm{h})$. We calculated accessibility as the inverse of isolation (eq.1).

Accessibility $=\frac{1}{\sum\left(d_{i} / v_{i}\right)+1}$

Where $d_{i}$ is the length of a single segment and $v_{i}$ the speed used on it. Accessibility ranges between 0 and 1. For instance, an accessibility of $\mathrm{O} \mathrm{h}^{-1}$ means that the census is at an infinite distance from the capital 
city, so the less accessible reef. Conversely, an accessibility of $1 \mathrm{~h}^{-1}$ means that the census is located in the capital city, so the most accessible reef.

To test whether management measures can protect shark populations along the gradient of accessibility we took advantage of 15 MPAs established in New Caledonia that vary in terms of age, size, restriction and travel time from Nouméa to embrace a wide range of conditions (Table 1). The MPA features were unbalanced and did not allow testing them separately. We thus included the management in the model using 4 categories along a gradient of restriction : open (no restriction), small no-take $\left(<30 \mathrm{~km}^{2}\right)$, large no-take $\left(>125 \mathrm{~km}^{2}\right)$ and large no -entry. This categorization split the no-take MPAs while accounting for their size.

We then used two benchmarks, the two extremes of the gradient, to evaluate protection effectiveness. First, remote areas (>25 hours of travel time) and a remote large no-entry MPA (Beautemps-Beaupré, $125 \mathrm{~km}^{2}, \approx 17$ hours of travel time), where human influence is thought to be the lowest (Maire et al. 2016), provide the upper baseline or a conservation target. Second, open areas easily accessible from Nouméa ( $<2$ hours of travel time) provide the other extreme of the gradient with a high level of human pressure. This created 6 composite categories along a gradient and shows which features produce which benefits for shark abundance and richness (Fig. 5). For instance, the difference between the accessible large no-take MPA (Aboré reserve) and the accessible large no-entry MPA (Merlet reserve) shows the benefit of the no-entry restriction.

\section{Boosted regression tree models}

Boosted Regression Trees (BRT) were used to model shark species richness and abundance. This method can cope with non-linear relationships and interactions between variables (Elith et al. 2008). A 10-fold cross validation of the model was performed and the cross validation correlation index was used to evaluate the model accuracy. Models were built using Poisson distributions. A range of parameters were 
used to maximize cross validation results (Table 2). The contribution of explanatory variables is function of the number of times they are selected in the weak classifiers during model construction. By accounting for the influence of a range of co-variables, BRT can detect marginal effects of explanatory variables (Elith et al. 2008).

Permutational pairwise tests (999 permutations) were used to compare categories of areas depending on their level of protection and their isolation from the capital city and accounting for other factors using BRT (Table S1). A Bonferroni correction was used to adjust p-values across the multiple tests.

All analyses were performed using R statistical software including the libraries RVAideMemoire, dismo and gbm for permutational pairwise tests and BRT respectively (R Core team 2012, Hervé 2014, Hijmans et al. 2013, Ridgeway 2007).

\section{Results}

\section{Distribution of shark species richness and abundance}

A total of 1364 sharks from 9 species and 4 families were recorded (Table 3) in 209 videos out of 385 (54\% occurrence) and in 421 visual censuses out of 2790 (15\% occurrence). Grey reef sharks (Carcharhinus amblyrhynchos) and whitetip reef sharks (Triaenodon obesus) were the most frequent species observed in both BRUVS ( $39 \%$ and $26 \%$ of videos respectively) and UVC ( $6 \%$ and $12 \%$ of censuses respectively) (Table 3, Fig. S1). Mean shark richness was 1.4 ( $\pm 0.6 \mathrm{SD})$ and $1.2( \pm 0.4 \mathrm{SD})$ species in BRUVS and UVC, respectively. Mean shark abundance was 1.5 ( \pm 2.2 SD) and 0.3 ( \pm 1.0 SD) individuals in BRUVS and UVC, respectively. Both species richness and abundance were on average higher in remote areas than in no-take MPAs and no-entry MPAs. For instance, a mean shark abundance of 2.9 ( \pm 2.6 SD) individuals per BRUVS was recorded in remote areas while 2.6 ( $\pm 2.9 \mathrm{SD})$ was observed in no-entry MPAs 
and 0.6 ( $\pm 0.8 \mathrm{SD})$ in no-take MPAs. Observations with the highest shark abundance (8-14 individuals) were all found in areas isolated from the mainland and from the regional capital, Nouméa (Fig. 1B).

\section{Predictors of shark species richness and abundance}

Using six explanatory variables, boosted regression tree (BRT) models explained between $54 \%$ and $66 \%$ of the variance across observations for, respectively, species richness and abundance of sharks (Table 2). The contribution of these explanatory variables (Fig. 3) revealed that reef accessibility, estimated by the inverse of the travel time from the capital city, was consistently by far the primary predictor (between 39 and $61 \%$ of total contribution) of shark species richness and abundance in both BRUVS and UVCs. Human density was a secondary predictor with a contribution ranging between 11 and $12 \%$ while management only accounted for between 0.6 and $13 \%$ of relative importance. Sea Surface Temperature (SST) and reef surface area around the census were other secondary predictors with a contribution ranging between $9-14 \%$ and $8.6-26 \%$, respectively. Reef habitat type had a contribution ranging between 5.2 - 11.9\% (Fig. S2).

The marginal effect of reef accessibility obtained with fitted values from the BRT model shows that both species richness and abundance of sharks decreased with increasing accessibility from the capital city (Fig. 4). Relative to remote areas (travel time $>25 \mathrm{~h}$, accessibility $<0.04 \mathrm{~h}^{-1}$ ), we predicted a decrease of $53.9 \%$ in shark species and $80.2 \%$ in shark individuals in areas located less than 1 hour of travel time (accessibility $<0.5 \mathrm{~h}^{-1}$ ) from the capital city using BRUVS. This reduction was even more pronounced in UVCs with a decrease of $94.5 \%$ in species richness and a decrease of $97 \%$ in abundance using the same comparison (Fig. 4).

\section{Protection effectiveness of sharks}


Pairwise permutation tests show that the six categories of management led to significantly different levels of shark species richness and number of individuals $(p<0.05)$ while controlling for other variables (Fig. 5). With BRUVS, shark richness and abundance were significantly higher in remote areas and in the remote no-entry MPA than in accessible open areas and in any MPA near humans even in the largest, oldest, and no-entry Merlet MPA. The highest average value (1.4 species and 4.4 individuals) was detected in the remote no-entry Beautemps-Beaupré MPA using BRUVS. Small no-take MPAs had levels of shark species richness and abundance as low as in accessible open areas. Even more marked differences between remote areas and all other management categories were predicted using UVC. For instance, the accessible large no-entry Merlet MPA had $45.3 \%$ fewer shark species and $79.8 \%$ fewer individuals than remote areas using UVC while BRUVS revealed $17.3 \%$ fewer shark species and $37.2 \%$ fewer shark individuals for the same comparison.

\section{Discussion}

By modeling the species richness and abundance of reef sharks using multiple explanatory variables we show that human activities are primarily responsible for shark depletion, even in the absence of direct fishing (shark fishing was historically absent and formerly banned in 2013 in the exclusive economic zone of New-Caledonia). We thus demonstrate that MPAs have a limited net benefit for sharks beyond the remoteness from human activities. Indeed, one of the world's oldest (43 years), most restrictive (noentry) and largest MPA $\left(172 \mathrm{~km}^{2}\right)$ on coral reefs cannot support the reference levels of shark richness and abundance since easily accessible from the capital city (less than 2 hours of travel time).

Our study demonstrates that remote areas support unique ecological roles and processes. As accessibility to humans increases, these ecological values are eroded, even in large and well-managed MPAs with key conservation features (Edgar et al. 2014). Remote areas may therefore act as the last sanctuaries and sources for highly vulnerable species like sharks. With less than 0.48 individual and 0.53 
species per hour of BRUVS and less than 0.05 individual and 0.05 species per $1000 \mathrm{~m}^{2}$ using UVC, we can consider that shark functional roles are almost extinct at less than $1 \mathrm{~h}$ from humans, regardless of the management or conservation efforts, with potential consequences for coral reef health (Roff et al. 2016). In addition to top-down control, sharks are very likely to exert a wide range of functions that remain to be quantified (Roff et al. 2016). For example, sharks may be involved in nutrient cycling (Schmitz et al. 2010), nutrient transport between different areas and habitats (Heupel \& Simpfendorfer 2015, Papastamatiou et al. 2015, McCauley et al. 2012), scavenging (Wilson \& Wolkovitch 2010, Dudley et al. 2000), invasive species removal (Wallach et al. 2015), diseased and weak individual removal (Chakraborty et al. 2015) as well as food web stability (Wallach et al. 2015).

The observed contrasts between remote areas and exploited areas or MPAs are probably very conservative due to major conservation efforts in New-Caledonia (no-entry and old MPAs, no shark fishing). We would thus expect this gradient to be more pronounced in the developing world where MPAs are typically younger and less enforced (Marinesque et al. 2012) and where fishing pressure is higher (Teh et al. 2013). Shark fishing is historically absent in New Caledonia with almost no reported commercial catch in the last 14 years and recreational shark fishing considered unlikely (Table S2, Gardes et al. 2014). Our independent observations using BRUVS and UVC, combined with trends in fishery catch reports, thus present multiple lines of evidence for a dramatic human footprint on shark species richness and abundance ( $90 \%$ lower) arising from factors other than fishing. This suggests that alternative factors to direct extraction are at play unless chronic shark fishing, that cannot be discounted, can explain such a decline over decades. For instance, fishing shark preys and human disturbance can impact shark fitness, richness and abundance (Bejder et al. 2006, Williams et al. 2006). The increase of the number of recreational users in no-take areas within the south-west lagoon in the past ten years supports the human disturbance hypothesis (Gonson et al. 2016). 
Unlike no-entry MPAs, no-take MPAs show little to no benefit for reef sharks even if large and well enforced. It supports the idea that human activities generate deleterious effects beyond direct fishing so the exclusion of human presence is key to protect reef shark populations. The large, no-entry and old Merlet MPA offers significant benefits to reef sharks but cannot support levels observed remote areas due to its proximity to humans. Trying to restore shark populations to their 'pristine' state close to humans appears unrealistic and would meet opposition from lagoon users. Instead, setting realistic conservation targets, given a degree of accessibility from humans, for the conservation of reef shark populations seems more relevant for managers. Well enforced, large and no-entry MPAs like Merlet provide a conservation target close to humans. However, establishing such restrictive MPAs in a humandominated seascape remains challenging particularly in developing countries where few alternatives exist for food security (Barange et al. 2014). In countries less dependent on coastal fisheries, agreements between policy makers, tourism professionals and fishermen are necessary preliminary steps.

Remote areas provide absolute targets often inapplicable close to humans and have an irreplaceable role in the protection of reef sharks as they host the largest populations. We do not dismiss the merit of MPAs in proximity to humans, with respect to the specific purpose of sustaining high diversity, density and biomass of key groups like herbivorous fish (MacNeil et al. 2015), or maintaining ecosystem resilience in general (Duffy et al. 2016, Emslie et al. 2015, Micheli et al. 2012). However, MPAs should not be assumed to provide absolute references for all aspects of biodiversity or ecosystem, particularly when easily accessible to humans. Our results also suggest that placing conservation efforts in remote areas can be valuable for preserving vulnerable species. At the time of intense debates about the usefulness of remote or 'residual' MPAs (DeVillers et al. 2014, Jones \& De Santo 2016) within the context of reaching conservation targets of the Convention on Biological Diversity (CBD), we show the unique role that such MPAs may play particularly for mobile megafauna. At the same time, small and 
metropolitan MPAs must concentrate most of conservation efforts on coral reefs since a majority of them (58\%) are within 30 minutes travel time of the nearest human settlement (Maire et al. 2016).

The sea surface temperature has a non negligible contribution in the models but the mechanism through which it directly affects shark physiology or indirectly via trophic relations remain unclear (Jennings et al. 2008, Brown et al. 2004, Ernest et al. 2003). . The type of coral reef habitat and its surface have contributions ranging between 5 and 26\%. Reef type and area are known as important predictors of reef shark diversity (Espinoza et al. 2014, Rizzari et al. 2014b). Additionally, reef type and area are major determinants of reef fish diversity (Grimaud \& Kulbicki 1998, Parravicini et al. 2013). Given the strong relationship between fish species richness and fish biomass (Mora et al. 2011, Duffy et al. 2016), we hypothesize that reef sharks should find more prey biomass on larger reefs.

The discrepancy between results obtained with the two methods (BRUVS and UVC), with BRUVS recording more species and individuals, may be explained by the ability of the bait to attract elusive individuals that may often be unnoticed by divers. UVC-only surveys thus arguably lack sensitivity to detect certain effects of MPAs in protecting reef sharks. The use of baited videos may reveal hidden levels of diversity and abundance for apex and mobile predators. More precisely, our BRUVS observations clearly highlight the benefit provided by MPAs under three conditions: isolated from humans (i.e. hardly accessible) with key features such as being large and no-entry. In small no-take MPAs the abundance of sharks is so low (mean $\pm S D=0.4 \pm 0.1$ individual per BRUVS) that conservation benefits are limited, consistent with observations from the highly-impacted environment of the Caribbean (WardPaige et al. 2010).

\section{Conclusion}

As human population will rise in the near future, particularly along the coast of developing countries, we would expect that very few reefs will remain remote and small metropolitan MPAs will experience even 
more human pressure(Burke et al. 2011). This additional human pressure for food and jobs will impact the most vulnerable ecosystems and species, regardless conservation efforts. Within the context of difficulties to create no-entry or even no-take MPAs near human activities (Watson et al. 2015, McClanahan et al. 2012), locating future highly restrictive MPAs in remote areas to reduce opposition from stakeholders and reach the target outlined in the Convention on Biological Diversity established in Nagoya in 2010 (10\% of sea coverage by MPAs by 2020) can appear as a sensible strategy. However, conservation benefits from such "residual" MPAs can be questionable particularly for fisheries and associated with high enforcement costs (Devillers et al. 2014, Singleton \& Roberts 2014). Our results show that remote areas can offer the last refuges for depleted megafauna and absolute reference conditions to evaluate management options under anthropogenic pressures. Additionally, remote areas can become emblematic places for promoting marine conservation through the media given their unique species assemblages but urgently require additional protection (White et al. 2017, Watson et al. 2016, Singleton \& Roberts 2014). We thus encourage policy makers to place the most isolated areas, which host unique and abundant marine life, under protection status at minimal conflicts. By contrast, no-take MPAs near humans are unlikely to host high diversity and abundance of sharks and should not be promoted to protect such mobile predators and should focus on other realistic targets instead. They can, for instance, be very effective in sustaining high biomass of key groups like herbivores (MacNeil et al. 2015), seeding adjacent exploited areas (Hopf et al. 2016) or providing recreational and educational benefits (Rees et al. 2015).

\section{Author's contributions}

Concept, J.B.J, L.V., D.M. and L.W.; Data Analysis, J.B.J., L.V., D.M., L.W. and M.K.; Resources, L.V., T.B.L. and J.J.M.; Writing - Review \& Editing, all.

\section{Acknowledgement}


We especially thank Gérard Mou-Tham and Joseph Baly for processing a large quantity of stereo footages. We are grateful to the crews of R/V Amborella and R/V Alis, the two vessels we used in the study. This study is part of the PRISTINE project funded by the TOTAL foundation. We would like to thank José Fabricio Vargas for some of the scientific drawings of sharks used in the supplementary material. We thank Dr. Justin Rizzari and Dr. Rowan Trebilco for valuable comments on the manuscript.

\section{Data accessibility}

The database used is this study will be archived in IRD repository and may be available upon request to laurent.vigliola@ird.fr.

\section{References}

Barange, M., Merino, G., Blanchard, J.L., Scholtens, J., Harle, J., Allison, E.H., Allen, J.I., Holt, J. \& Jennings, S. (2014) Impacts of climate change on marine ecosystem production in societies dependent on fisheries. Nature Climate Change, 4, 211-216.

Bejder, L., Samuels, A., Whitehead, H., Gales, N., Mann, J., Connor, R., Heithaus M., Watson-Capps, J., Flaherty, C. \& Krützen, M. (2006) Decline in relative abundance of bottlenose dolphins exposed to long-term disturbance. Conservation Biology, 20, 1791-1798.

Brewer, T.D., Cinner, J.E., Green, A. \& Pressey, R.L. (2013) Effects of human population density and proximity to markets on coral reef fishes vulnerable to extinction by fishing. Conservation Biology, $\mathbf{0}$, 1-10.

Brown, J.H., Gilooly, J.F., Allen, A.P., Savage, V.M. \& West, G.B. (2004) Toward a metabolic theory of ecology. Ecology, 85, 1771-1789. 
Brunnschweiler, J.M. \& Ward-Paige, C.A. (2014) Shark fishing and tourism. Oryx, 48, 486-487.

Burke, L., Reytar, K., Spalding, M. \& Perry, A. (2011) Reefs at risk revisited. World Resource Institute, Washington, 130p.

Cappo, M., Harvey, E.S. \& Shortis, M. (2006) Counting and measuring fish with baited video techniques an overview. ASFB Workshop Proceedings, 101-114.

Chakraborty, S., Kooi, B.W., Biswas, B. \& Chattopadhyay, J. (2015) Revealing the role of predator interference in a predator-prey system with disease in prey population. Ecological Complexity, 21, 100-111.

Chen, H. \& Kishino, H. (2015) Global pattern of phylogenetic species composition of shark and its conservation priority. Ecology and Evolution, 5, 4455-4465.

Cinner, J.E., Huchery, C., MacNeil, A., Graham, N.A.J., McClanahan, T.R., Maina, J., Maire, E., Kittinger, J.N. et al. (2016) Bright spots among the world's coral reefs. Nature, 535, 416-419.

Cinner, J.E., McClanahan, T.R., Daw, T.M., Graham, A.J., Maina, J., Wilson, S.K. \& Hughes, T.P. (2009) Linking social and ecological systems to sustain coral reef fisheries. Current Biology, 19, 206-212.

Cisneros-Montemayor, A.M., Barnes-Mauthe, M., Al-Abdulzarrak, D., Navarro-Holmes, E. \& Sumaila, U.R. (2013) Global economic value of shark ecotourism: implications for conservation. Oryx , 47, 381-388.

Devillers, R., Pressey, R., Grech, A., Kittinger, J.N., Edgar, G.J., Ward, T. \& Waltson, R. (2014) Reinventing residuals reserves in the sea: are we favouring ease of establishment over need for protection? Aquatic Conservation: Marine and Freshwater Ecosystems, 25, 480-504. 
Dickens, L.C., Goatley, C.H.R., Tanner, J.K. \& Bellwood, D.R. (2010) Quantifying relative diver effects in underwater visual censuses. PLOS ONE, 6, e18965.

Dudley, S.F.J., Anderson-Reade, M.D., Thompson, G.S. \& McMullen, P.B. (2000) Concurrent scavenging off a whale carcass by great white sharks, Carcharodon carcharias, and tiger sharks, Galeocerdo cuvier. Fisheries Bulletin, 98, 646-649.

Duffy, J.E., Lefcheck, J.S., Stuart-Smith, R.D., Navarette, S.A. \& Edgar, G.J. (2016) Biodiversity enhances reef fish biomass and resistance to climate change. Proceedings of the National Academy of Sciences of the United States of America, 113, 6230-6235.

Dulvy, N.K., Fowler, S.L., Musick, J.A.M., Cavanagh, R.D., Kyne, P.M., Harrison, L.R., Carlson, J.K., Davidson, L.N.K., Fordham. S.V., Francis, M.P. et al. (2014) Extinction risk and conservation of the world's shark and rays. ELife, 3, e00590.

Edgar, G.J., Stuart-Smith, R.D., Willis, T.J., Kininmonth, S., Baker, S.C., Banks, S., Barrett, N.S., Becerro, M.A., Bernard, A.T.F., Berkhout, J. et al. (2014) Global conservation outcomes depend on marine protected areas with five key features. Nature, 506, 216-220.

Elith, J., Leathwick, J.R., \& Hastie, T. (2008) A working guide to boosted regression trees. Journal of Animal Ecology, 77, 802-813.

Emslie, M.J., Logan, M., Williamson, D.H., Ayling, A.M., MacNeil, M.A., Ceccarelli, D., Cheal, A.J., Evans, R.D., Johns, K.A., Jonker, M.J. et al. (2015) Expectations and outcomes of reserve network performance following re-zoning of the Great Barrier Reef Marine Park. Current Biology, 25, 983-992. 
Ernest, S.K.M., Enquist, B.J., Brown, J.H., Charnov, E.L., Gilooly, J.F., Savage, V.M., White, E.P., Smith, F.A., Hadly, E.A., Haskell, J.P. et al. (2003) Thermodynamic and metabolic effects on the scaling of production and population energy use. Ecology Letters, 6, 990-995.

Espinoza, M., Cappo, M., Heupel, M.R., Tobin, A.J. \& Simpfendorfer, C.A. (2014) Quantifying shark distribution patterns and species-habitat associations: implications of marine park zoning. PLOS ONE, 9, e106885.

Field, I.C., Meekan, M.G., Buckworth, R.C. \& Bradshaw, C.J.A. (2009) Susceptibility of sharks, rays and chimaeras to global extinction. Advances in Marine Biology, 56, 275-363.

Frisch, A.J., Ireland, M., Rizzari, J.R., Lönnstedt, O.M., Magnenat, K.A., Mirbach, C.E. \& Hobbs, J-P.A. (2016) Reassessing the trophic role of reef sharks as apex predators on coral reefs. Coral Reefs, 35, 459-472.

Gardes, L., Tessier, E., Allain, V., Alloncle, N., Baudat-Franceschi, J., Butaud, JF., Collot, J., Etaix-Bonnin, R., Hubert, A., Jourdan, H. et al. (2014) Analyse stratégique de l'espace maritime de la NouvelleCalédonie - vers une gestion intégrée. Agence des aires marines protégées, Gouvernement de la Nouvelle-Calédonie éditeurs, 395 p. DOI: 10.13140/RG.2.1.2888.0803

Gonson, C., Pelletier, D., Gamp, E., Preuss, B., Jollit, I. \& Ferraris, J. (2016) Decadal increase in the number of recreational users is concentrated in no-take marine reserves. Marine Pollution Bulletin, 107, 144154.

Graham, N.A.J. \& McClanahan, T.R. (2013) The last call for marine wilderness? BioScience, 63, 397-402. 
Graham, N.A.J., Spalding, M.D. \& Sheppard C.R. (2010) Reef shark declines in remote atolls highlight the need for multi-faceted conservation action. Aquatic Conservation: Marine and Freshwater Ecosystems, 20, 543-548.

Grimaud, J. \& Kulbicki, M. (1998) Influence de la distance à l'océan sur les peuplements ichtyologiques des récifs frangeants de Nouvelle-Calédonie. Comptes Rendus de l'Académie des Sciences de Paris Série 3 : Sciences de la Vie, 321, 923-931.

Hervé, M. (2014). RVAideMemoire: Diverse basic statistical and graphical functions. R package version 0.9-32. http://CRAN.R-project.org/package=RVAideMemoire.

Heupel, M.R. \& Simpfendorfer, C.A. (2015) Long-term movement patterns of a coral reef predator. Coral Reefs, 34, 679-691.

Hijmans, R.J., Phillips, S., Leathwick, J. \& Elith, J. (2013) dismo: Species distribution modeling, R package ver. 0.9-3, <http://CRAN.R-project.org/package=dismo $>$.

Hopf, J.K., Jones, G.P., Williamson, D.H. \& Connolly, S.R. (2016) Fishery consequences of marine reserves: short-term pain for long-term gain. Ecological Applications, 26, 818-829.

Jennings, S., Mélin, F., Blanchard, J.L., Forster, R.M., Dulvy, N.K. \& Wilson, R.W. (2008) Global-scale predictions of community and ecosystem properties from simple ecological theory. Proceedings of the Royal Society B: Biological Sciences, 275, 1375-1383.

Jones, P.J.S. \& De Santo, E.M. (2016) Is the race for remote, very large marine protected areas (VLMPAs) taking us down the wrong track ? Marine Policy, 73, 231-234. 
Kulbicki, M. \& Sarramegna, S. (1999) Comparison of density estimates derived from strip transect and distance sampling for underwater visual censuses: a case study of Chaetodontidae and Pomacanthidae. Aquatic Living Resources, 12, 315-325.

Labrosse, P., Kulbicki, M. and Ferraris, J. (2002) Underwater visual fish census surveys. Proper use and implementation. Reef resource assessment tools (Noumea : Secretariat of the Pacific Community).

MacNeil, M.A., Graham, N.A.J., Cinner, J.E., Wilson, S.K., Williams, I.D., Maina, J., Newman, S., Friedlander, A.M., Jupiter, S., Polunin, N.V.C. \& McClanahan, T.R. (2015) Recovery potential of the world's coral reef fishes. Nature, 520, 341-344.

Maire, E., Cinner, J., Velez, L., Huchery, C., Mora, C., Dagata, S., Vigliola, L., Wantiez, L., Kulbicki, M., \& Mouillot, D. (2016) How accessible are coral reefs to people? A global assessment based on travel time. Ecology Letters, 19, 351-360.

Marinesque, S., Kaplan, D.M. \& Rodwell, L.D. (2012) Global implementation of marine protected areas: Is the developing world being left behind? Marine Policy, 36, 727-737.

McCauley, D.J., Young, H.S., Dunbar, R.B., Estes, J.A., Semmens, B.X. \& Micheli, F. (2012) Assessing the effects of large mobile predators on ecosystem connectivity. Ecological Applications, 22, 1711-1717.

McClanahan, T.R., Abunge, C.A. \& Cinner, J.E. (2012) Heterogeneity in fishers' and managers' preferences towards management restrictions and benefits in Kenya. Environmental Conservation, 39, 1-13.

McClenachan, L., Cooper, A.B. \& Dulvy, N.K. (2016) Rethinking trade-driven extinction risk in marine and terrestrial megafauna. Current Biology, 26, 1-7. 
McCook, L.J., Ayling, T., Cappo, M., Choat, J.H., Evans, R.D., De Freitas, D.M., Heupel, M., Hughes, T.P., Jones, G.P., Mapstone, B. et al. (2010) Adaptive management of the Great Barrier Reef: A globally significant demonstration of the benefits of networks of marine reserves. PNAS 107, 18278-18285.12. Robbins, W.D., Hisano, M., Connoly, S.R. \& Choat, J.H. (2006) Ongoing collapse of coral-reef shark populations. Current Biology, 16, 2314-2319.

Micheli, F., Saenz-Arroyo, A., Greenley, A., Vazquez, L., Montes, J.A.E., Rossetto, M. \& De Leo, G.A. (2012) Evidence that marine reserves enhance resilience to climatic impacts. PLOS ONE, 7, e40832.

Mora, C., Aburto-Oropeza, O., Ayala Bocos, A., Ayotte, P.M., Banks, S. et al. (2011) Global Human Footprint on the Linkage between Biodiversity and Ecosystem Functioning in Reef Fishes. PLoS Biology, 9, e1000606.

Nadon, M.O., Baum, J.K., Williams, I.D., McPherson, J.M., Zgliczynski, B.J., Richards, B.L., Schroeder, R.E. \& Brainard, R.E. (2012) Re-creating missing population baselines for pacific reef sharks. Conservation Biology, 3, 493-503.

Papastamatiou, Y.P., Meyer, C.G., Kosaki, R.K., Wallsgrove, N.J. \& Popp, B.N. (2015) Movements and foraging of predators associated with mesophotic coral reefs and their potential for linking ecological habitats. Marine Ecology Progress Series, 521, 155-170.

Parravicini, V., Kulbicki, M., Bellwood, D.R., Friedlander, A.M., Arias-Gonzales, E., Chabanet, P., Floeter, S., Vigliola, L., D'Agata, S., Myers, R. \& Mouillot, D. (2013) Global patterns and predictors of tropical reef fish species richness. Ecography, 36, 001-009.

R Core team (2016) R: a language and environment for statistical computing, R Foundation for Statistical Computing, Vienna, Austria, http://www.R-project.org/. 
Rees, S.E., Mangi, S.C., Hattam, C., Gall, S.C., Rodwell, L.D., Peckett, F.J. \& Attrill, M.J. (2015) The socioeconomic effects of a Marine Protected Area on the ecosystem service of leisure and recreation. Marine Policy, 62, 144-152.

Ridgeway, G. (2007) gbm: generalized boosted regression models, R package ver. 1.6-3, <http://cran.rproject.org/ web/packages/gbm.pdf>.

Rizzari, J.R., Frisch, A.J. \& Connoly, S.R. (2014a) How robust are estimates of coral reef shark depletion ? Biological Conservation, 176, 39-47.

Rizzari, J.R., Frisch, A.J. \& Magnenat, K.A. (2014b) Diversity, abundance, and distribution of reef sharks on outer-shelf reefs of the Great Barrier Reef, Australia. Marine Biology, 161, 2847-2855.

Robbins, W.D., Hisano, M., Connolly, S.R. \& Choat, J.H. (2006) Ongoing collapse of coral-reef populations. Current Biology, 16, 2314-2319.

Roff, G., Doropoulos, C., Rogers, A., Bozec, Y.M., Krueck, N.C., Aurellado, E., Priest, M., Birrell, C. \& Mumby, P.J. (2016) The ecological role of shark on coral reefs. Trends in Ecology and Evolution. 31, 395-407.

Sandin, S.A., Smith, J.E., Demartini, E.E., Dinsdale, E.A., Donner, S.D., Friedlander, A.M., Konochick, T., Malay, M., Maragos, J.E.,Obura, D. et al. (2008) Baselines and degradation of coral reefs in the northern line Islands. PLOS ONE, 3, e1548.

Schmitz, O., Hawlena, D. \& Trussell, G.C. (2010) Predator control of ecosystem nutrient dynamics. Ecology Letters, 13, 1199-1209. 
Singleton, R.L. \& Roberts, C.M. (2014) The contribution of very large marine protected areas to marine conservation: giant leaps of smoke and mirrors? Marine Pollution Bulletin, 87, 7-10.

Teh, L.S.L., Teh, L.C.L., \& Sumaila,U.R. (2013) A global estimate of the number of coral reef fishers. PLoS ONE, 8, e65397.Wallach, A.D., Izhaki, I., Toms, J.D., Ripple, W.J. \& Shanas, U. (2015) What is an apex predator? Oikos, 00, 001-009.

Wallach, A.D., Ripple, W.J. \& Carroll, S.P. (2015) Novel trophic cascades: apex predators enable coexistence. Trends in Ecology and Evolution, 30, 146-153.

Ward-paige, C.A., Mora, C., Lotze, H.K., Pattengill-Semmens, C., McClenahan, L., Arias-Castro, E. \& Myers, R. (2010) Large-scale absence of sharks on reefs in the Greater-Caribbean: A footprint of human pressures. PLOS ONE, 5, e11968.

Watson, R.A., Nowara, G.B., Hartmann, K., Green, B.S., Tracey, S.R. \& Carter, C.G. (2015) Marine foods sourced from farther as their use of global ocean primary production increase. Nature Communications, 6, 1-6.

Watson, J.E.M., Shanahan, D.F., Di Marco, M., Allan, J., Laurance, W.F., Sanderson, E.W., Mackey, B. \& Venter, O. (2016) Catastrophic declines in wilderness areas undermine global environment targets. Current Biology, 26, 1-6.

White, T.D., Carlisle, A.B., Kroodsma, D.A., Block, B.A., Casagrandi, R., De Leo, G.A., Gatto, M., Micheli, F. \& McCauley, D.J. (2017) Assessing the effectiveness of a large marine protected area for reef shark conservation. Biological Conservation, 207, 64-71. 
Williams, J.D., Baum, J.K., Heenan, A., Hanson, K.M., Nadon, M.O. \& Bramard, R.E. (2015) Human, oceanographic and habitats drivers of central and western pacific coral reef fish assemblages. PLoS ONE, 10, e0120516.

Williams, R., Lusseau, D. \& Hammond, P.S. (2006) Estimating relative energetic costs of human disturbance to killer whales (Orcinus orca). Biological Conservation, 133, 301-311.

Wilson, E.E. \& Wolkovich, E.M. (2011) Scavenging: how carnivores and carrion structure communities. Trends in Ecology and Evolution, 26, 129-135. 


\section{Figures \& tables}

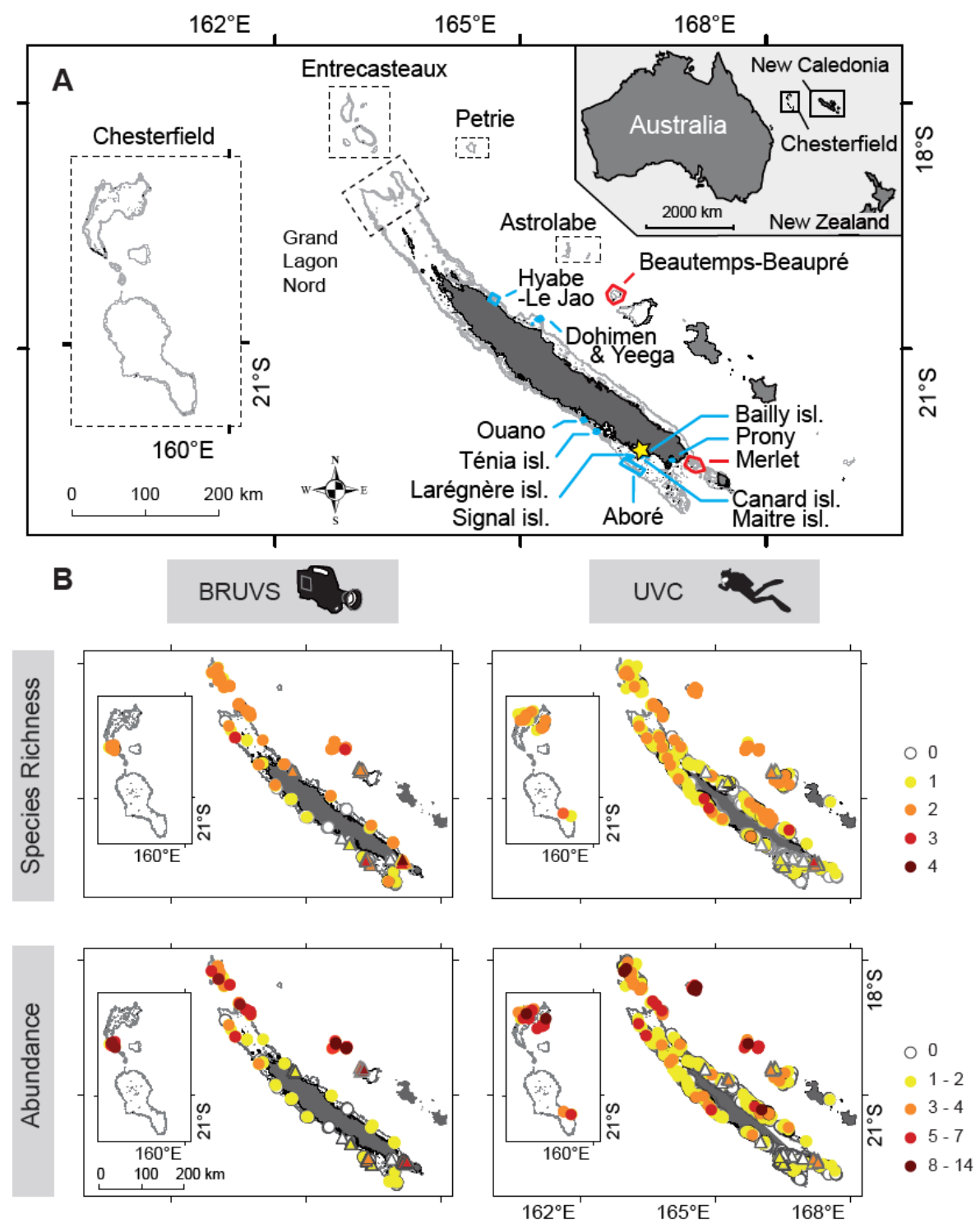

Fig. 1. Survey sites showing (A) location of marine protected areas and (B) species richness and abundance of sharks using Baited Remote Underwater Video Systems (BRUVS) and Underwater Visual Censuses (UVC). (A) The no-take MPA boundaries are in blue, the no-entry MPA boundaries are in red, remote areas are surrounded with dash lines and a yellow star symbolizes the capital city, Nouméa. The Kuendu MPA $\left(22^{\circ} 15^{\prime} 35^{\prime \prime} \mathrm{E} ; 166^{\circ} 23^{\prime} 11^{\prime \prime} \mathrm{S}\right)$ is too small to be symbolized on the map. See Table 1 for the full list of MPAs and their characteristics. 

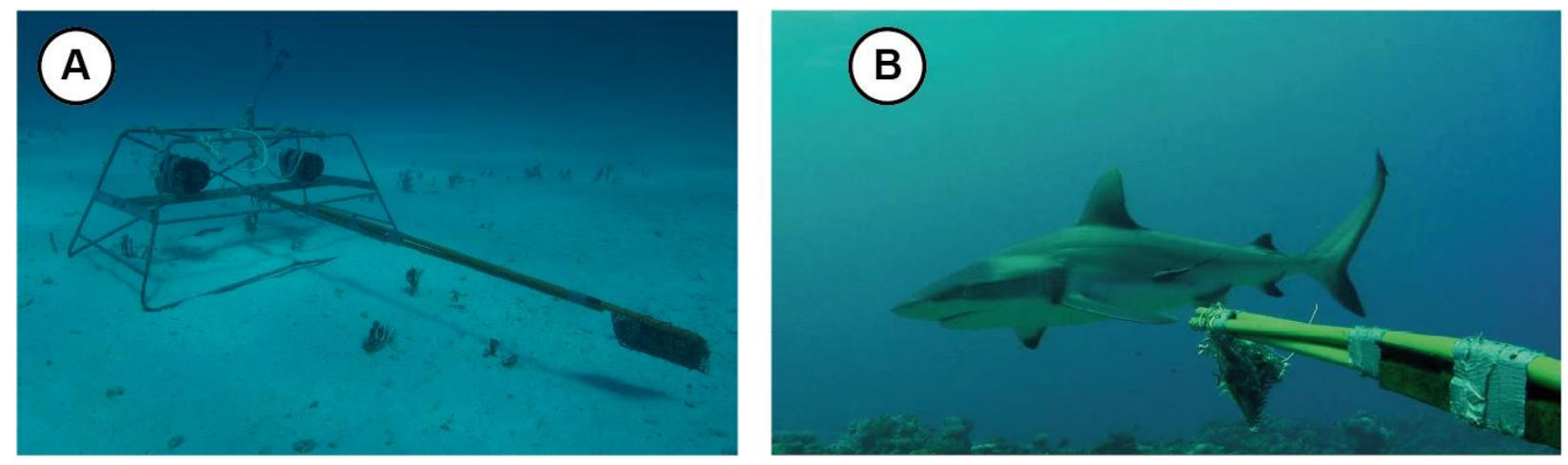

Fig. 2. Baited Remote Underwater Video (BRUVS) device (A) and a grey reef shark (Carcharhinus amblyrhynchos) spotted by the camera (B). 

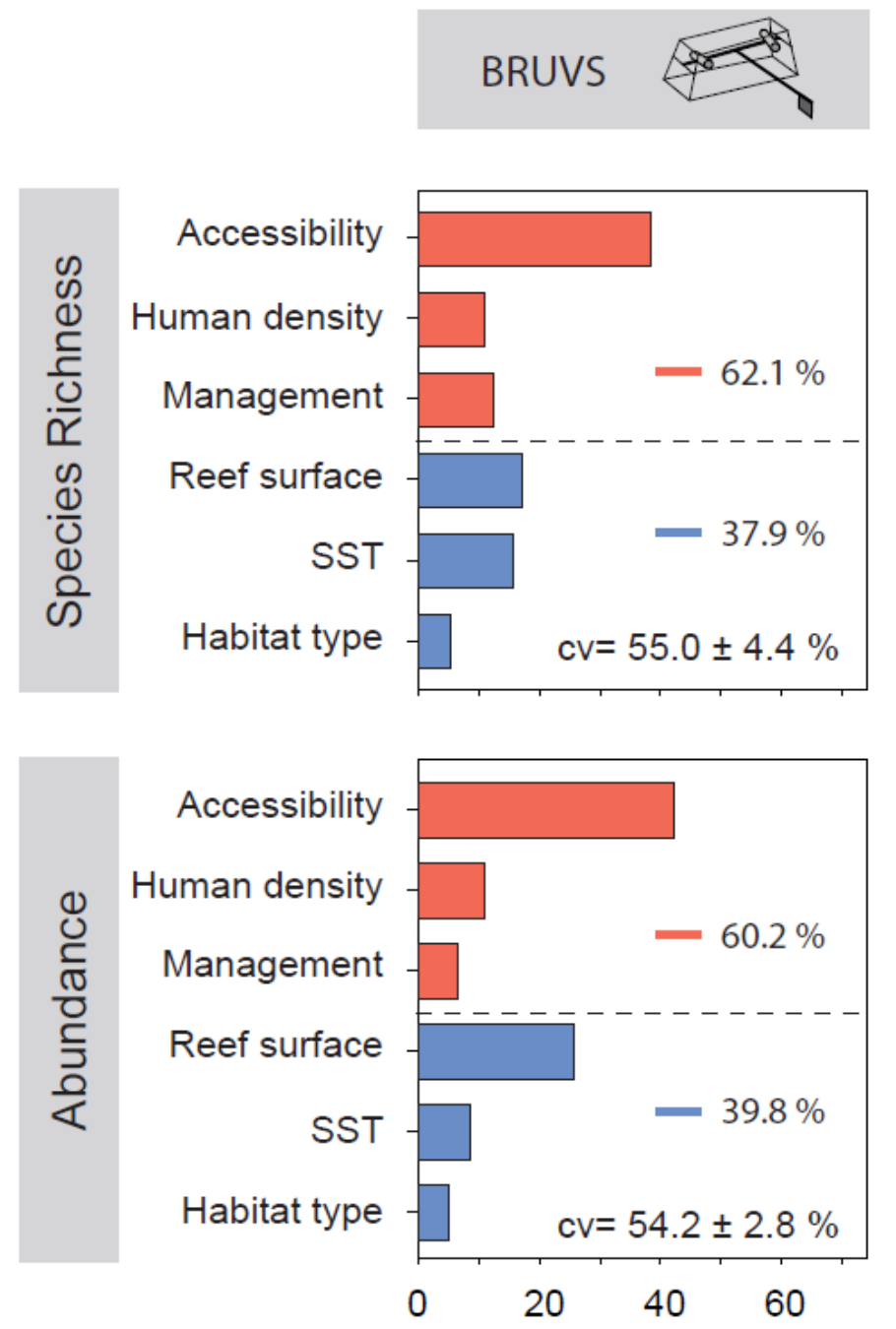

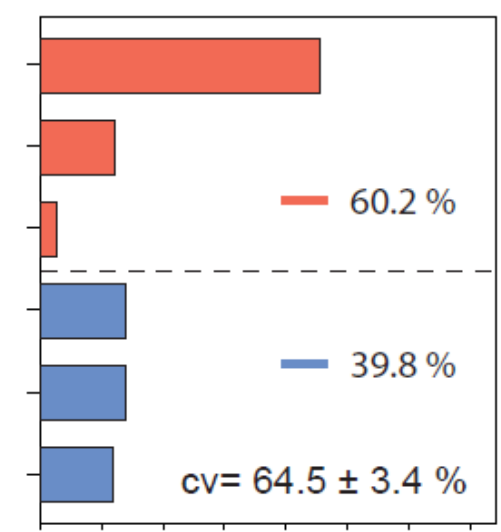

UVC
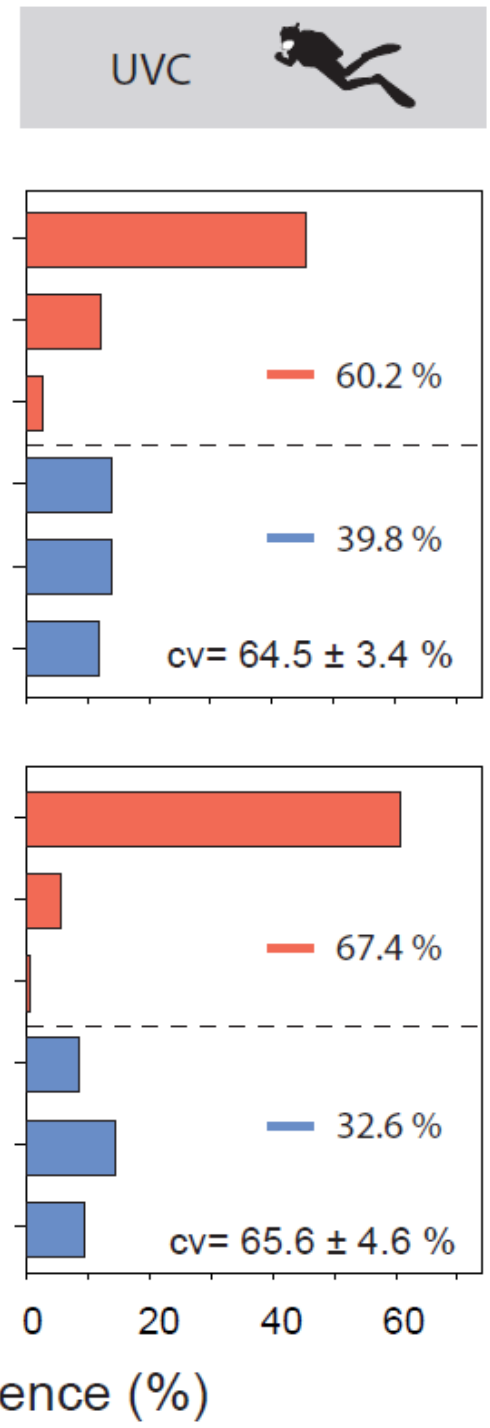

Fig. 3. Summary of the relative contributions (\%) of the five predictors used in Boosted Regression Trees (BRT) explaining species richness and abundance of sharks using Baited Remote Underwater Video Systems (BRUVS) and Underwater Visual Censuses (UVC). Accessibility: inverse of the travel time from the capital city and its market; Human density: Nearest human population density; Management: categories of management; Reef surface: reef surface surrounding the census; SST: Sea Surface Temperature; Habitat type: type of reef; cv: Cross Validation correlation used to evaluate the explained variance and thus the performance of the models. Human related variables are in red while environmental variables are in blue. The statistics of the models are provided in Table 2. 


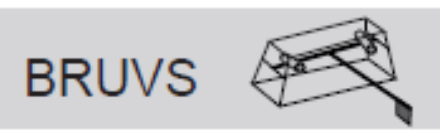

Travel time from market (h)
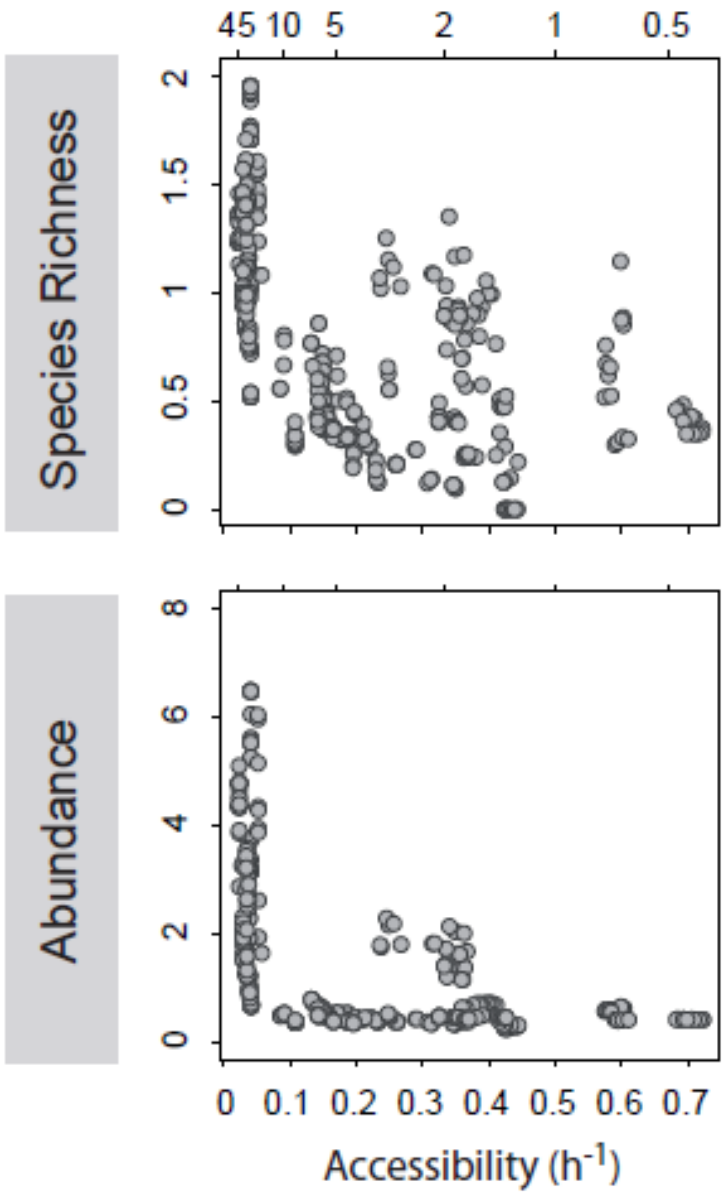

\section{UVC}

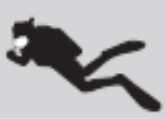

Travel time from market (h)
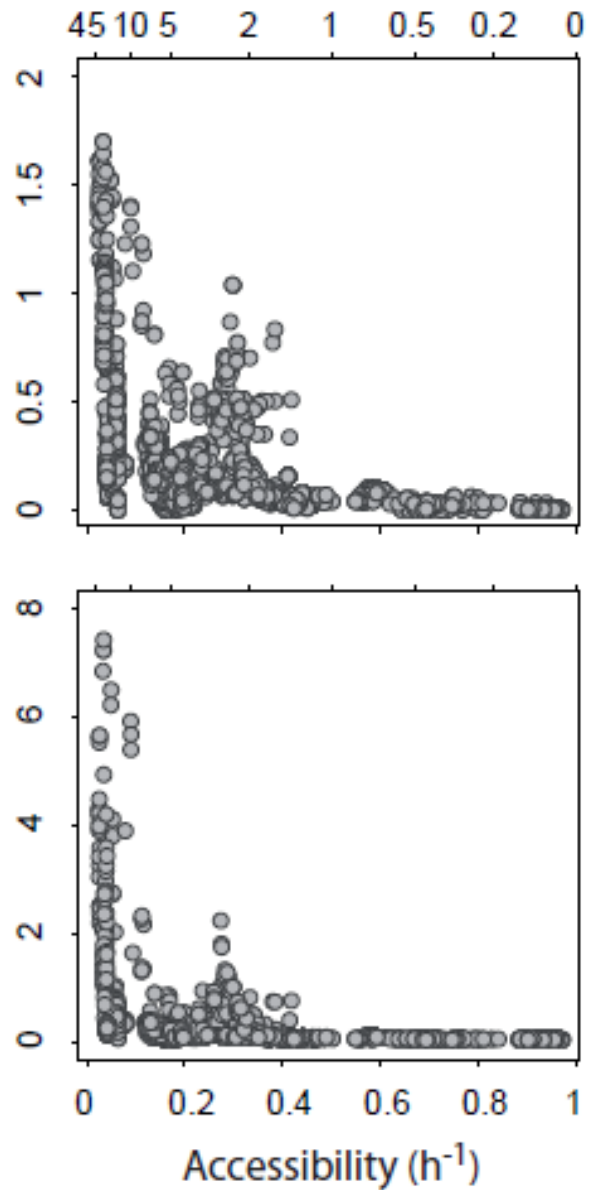

Fig. 4. Species richness and abundance of sharks as a function of the reef accessibility accounting for other factors using BRT models. Each dot represents one census. 

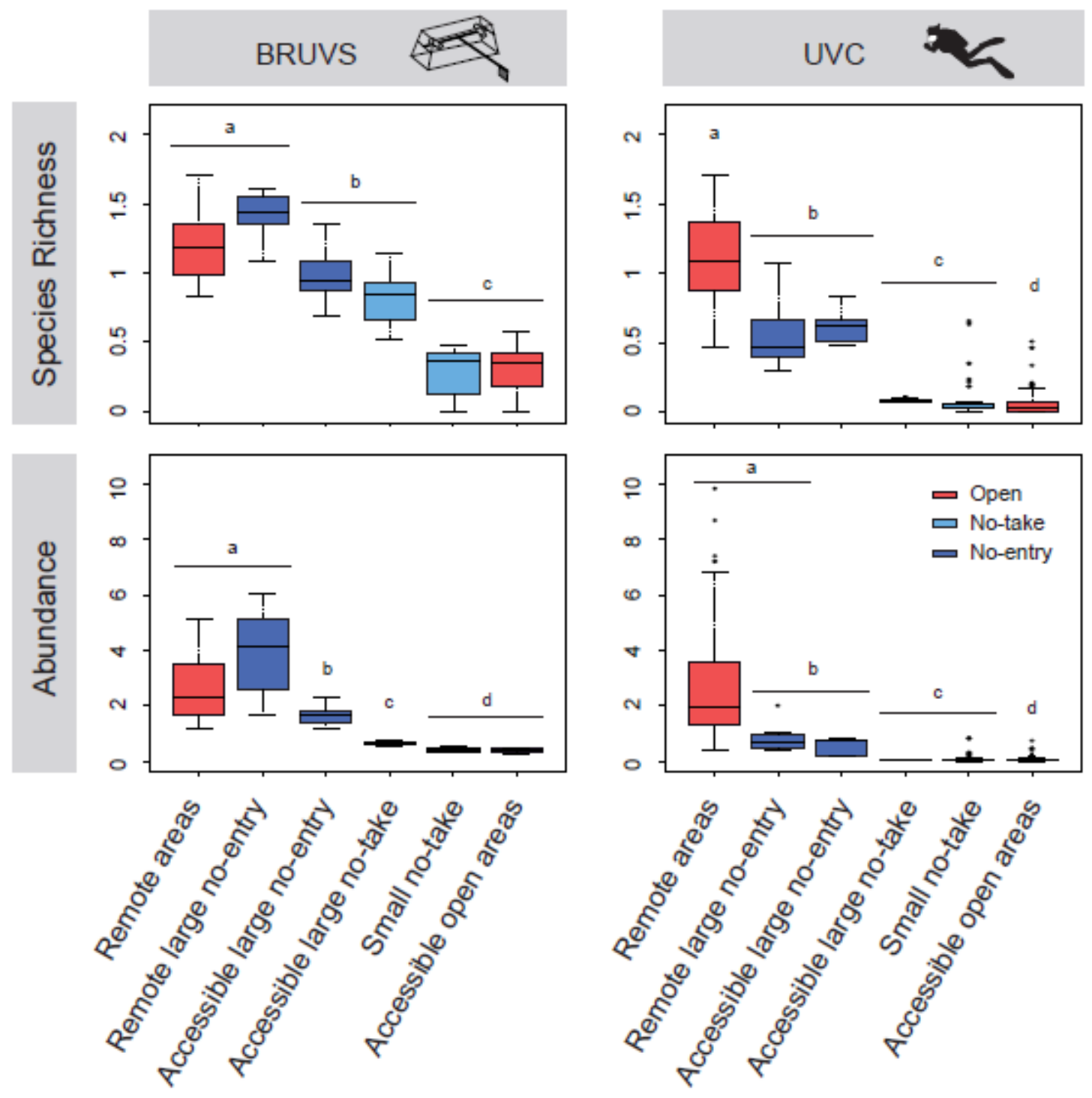

\section{Fig. 5. Species richness and abundance of sharks as a function of six categories of areas after}

accounting for other factors using BRT models. The four levels of management used in the model were split into six categories to account for their accessibility from the capital city (Noumea). Thus, these categories represent a gradient of accessibility from accessible areas ( $<2 \mathrm{~h}$ of travel time, red) to remote areas ( $>25 \mathrm{~h}$ of travel time, red), of management from no-take (light blue) to no-entry MPA (dark blue), and of size from small to large MPAs (See Table 1). Different letters indicate significant differences at $p$ value $<5 \%$ using permutational pairwise tests with 999 permutations. 
Table 1. Summary of Marine Protected Areas (MPAs) features sampled with Baited Remote Underwater Video Systems (BRUVS) and Underwater Visual Censuses (UVC) in New Caledonia. Noentry MPAs prohibit all human activities including the entrance of ships while no-take MPA allow nonextractive activities.

\begin{tabular}{|c|c|c|c|c|c|c|}
\hline $\begin{array}{l}\text { Marine protected } \\
\text { areas }\end{array}$ & Location & Status & $\begin{array}{l}\text { Surface } \\
\left(\mathrm{km}^{2}\right)\end{array}$ & $\begin{array}{l}\text { Creation } \\
\text { year }\end{array}$ & $\begin{array}{l}\text { Travel time } \\
\text { range }(\mathrm{h})\end{array}$ & Survey method \\
\hline Dohimen & Hienghène & No-take & 3.7 & 2010 & $4.49-5.74$ & UVC \\
\hline Yeega & Hienghène & No-take & 6.6 & 2010 & $4.49-5.74$ & UVC \\
\hline Ténia islet & La Foa & No-take & 10 & 1998 & $1.32-1.77$ & BRUVS \\
\hline Ouano & La Foa & No-take & 29.8 & 2004 & $1.87-1.91$ & BRUVS \\
\hline Aboré reef & Nouméa & No-take & 150 & $1981-96$ & $0.66-1.80$ & BRUVS, UVC \\
\hline Larégnère islet & Nouméa & No-take & 6.7 & 1989 & $0.41-0.47$ & BRUVS, UVC \\
\hline Bailly islet & Nouméa & No-take & 2.2 & 1989 & $0.36-0.38$ & UVC \\
\hline $\begin{array}{l}\text { Canard islet, } \\
\text { Ricaudy reef }\end{array}$ & Nouméa & No-take & 1.9 & 1989 & $0.06-0.06$ & UVC \\
\hline Maitre islet & Nouméa & No-take & 6.3 & 1981 & $0.19-0.26$ & UVC \\
\hline Signal islet & Nouméa & No-take & 2.5 & 1989 & $0.23-0.48$ & UVC \\
\hline Kuendu & Nouméa & No-take & 0.4 & 1998 & $0.30-0.81$ & UVC \\
\hline Hyabé-Le Jao & Pouébo & No-take & 13.3 & 2010 & $5.43-5.63$ & BRUVS, UVC \\
\hline Prony (2 sites) & Prony Bay & No-take & 1.5 & 1993 & $1.26-1.34$ & BRUVS, UVC \\
\hline (Yves) Merlet & Yaté & No-entry & 172 & 1970 & $1.61-3.26$ & BRUVS, UVC \\
\hline $\begin{array}{l}\text { Beautemps } \\
\text { Beaupré }\end{array}$ & $\begin{array}{l}\text { near } \\
\text { Ouvéa }\end{array}$ & No-entry & 125 & Unknown & $16.68-18.74$ & BRUVS, UVC \\
\hline
\end{tabular}


Table 2. Summary of settings and output for Boosted Regression Trees models (BRT) . The tree complexity represents the number of nodes in the regression trees, the learning rate represents the contribution of each tree generated and the bag fraction is the seed for stochastic process. The Cross Validation correlation (cv) was used to evaluate the explained variance and thus the performance of the models.

\begin{tabular}{llllllllll}
\hline Method & $\begin{array}{l}\text { Response } \\
\text { variable }\end{array}$ & $\begin{array}{l}\text { Learning } \\
\text { rate }\end{array}$ & $\begin{array}{l}\text { Tree } \\
\text { complexity }\end{array}$ & $\begin{array}{l}\text { Bag } \\
\text { fraction }\end{array}$ & $\begin{array}{l}\text { Number } \\
\text { of trees }\end{array}$ & $\begin{array}{l}\text { Mean total } \\
\text { dev. }\end{array}$ & $\begin{array}{l}\text { Mean res. } \\
\text { dev. }\end{array}$ & $\begin{array}{l}\text { Estimated cv } \\
\text { dev.( } \pm \text { SE) }\end{array}$ \\
\hline BRUV & Sp. richness & 0.002 & 2 & 0.5 & 4200 & 0.69 & 0.37 & $0.48 \pm 0.04$ & $0.55 \pm 0.04$ \\
& Abundance & 0.002 & 4 & 0.5 & 2300 & 2.72 & 1.14 & $1.49 \pm 0.07$ & $0.65 \pm 0.03$ \\
\multirow{3}{*}{ UVC } & Sp. richness & 0.001 & 2 & 0.5 & 3150 & 0.20 & 0.12 & $0.14 \pm 0.01$ & $0.54 \pm 0.03$ \\
& Abundance & 0.003 & 5 & 0.5 & 3750 & 1.23 & 0.55 & $0.67 \pm 0.03$ & $0.66 \pm 0.05$ \\
\hline
\end{tabular}


Table 3. Summary of shark species occurrence and abundance using Baited Remote Video Systems (BRUVS) and Underwater Visual Censuses (UVC).

\begin{tabular}{|c|c|c|c|c|c|c|c|}
\hline \multirow[t]{2}{*}{ Family } & \multirow[t]{2}{*}{ Species } & \multicolumn{2}{|c|}{ Occurrence (\%) } & \multicolumn{2}{|c|}{ Abundance (mean \pm SD) } & \multicolumn{2}{|c|}{$\begin{array}{c}\text { Relative } \\
\text { abundance (\%) }\end{array}$} \\
\hline & & BRUVS & UVC & BRUVS & UVC & BRUVS & UVC \\
\hline \multirow[t]{7}{*}{ Carcharhinidae } & Carcharhinus albimarginatus & 1.30 & 0.39 & $0.02 \pm 0.14$ & $0.003 \pm 0.06$ & 1.03 & 1.15 \\
\hline & Carcharhinus amblyrhynchos & 38.70 & 5.95 & $1.05 \pm 1.88$ & $0.13 \pm 0.75$ & 69.24 & 45.72 \\
\hline & Carcharhinus melanopterus & 5.71 & 1.58 & $0.06 \pm 0.26$ & $0.013 \pm 0.11$ & 4.12 & 4.60 \\
\hline & Carcharhinus sp. & 0.52 & 0 & $0.003 \pm 0.05$ & 0 & 0.17 & 0 \\
\hline & Galeocerdo cuvier & 1.82 & 0 & $0.02 \pm 0.13$ & 0 & 1.20 & 0 \\
\hline & Negaprion acutidens & 1.03 & 0.11 & $0.01 \pm 0.10$ & $0.001 \pm 0.03$ & 0.69 & 0.26 \\
\hline & Triaenodon obesus & 25.97 & 11.75 & $0.32 \pm 0.59$ & $0.13 \pm 0.42$ & 21.31 & 46.36 \\
\hline Ginglymostomatidae & Nebrius ferrugineus & 1.56 & 0.35 & $0.02 \pm 0.12$ & $0.004 \pm 0.07$ & 1.03 & 1.40 \\
\hline Sphyrnidae & Sphyrna lewini & 0.78 & 0.04 & $0.01 \pm 0.09$ & $0.0003 \pm 0.02$ & 0.52 & 0.13 \\
\hline \multirow[t]{2}{*}{ Stegostomatidae } & Stegostoma fasciatum & 1.04 & 0.18 & $0.01 \pm 0.10$ & $0.001 \pm 0.03$ & 0.69 & 0.38 \\
\hline & All species & 54.29 & 15.09 & $1.51 \pm 2.19$ & $0.33 \pm 1.08$ & - & - \\
\hline
\end{tabular}

